\title{
Acetate clearance rate as a potential index of the availability of glucogenic precursors in ruminants fed on roughage-based diets
}

\author{
BY P. B. CRONJË*, J. V. NOLAN AND R. A. LENG \\ Department of Biochemistry, Microbiology \& Nutrition, University of New England, Armidale, \\ NSW 2351, Australia
}

(Received 21 January 1990 - Accepted 28 February 1991)

\begin{abstract}
Three experiments were conducted to investigate interactions between acetate and glucose metabolism in sheep fed on roughage-based diets, and to establish whether the clearance rate of an intravenous acetate load would provide a valid index of the dietary acetate:glucogenic precursors ratio. In Expt 1 lambs were fed on a basal diet of wheat straw and supplemented with propionate and protein. Both supplements increased glucose irreversible loss rate (ILR) although not to the same degree. Acetate clearance rates were increased by protein and propionate supplementation and were positively related to glucose ILR irrespective of precursor. In Expt 2 the effects of an increased dietary load of acetate given with or without propionate were investigated. Glucose ILR did not respond to acetate supplementation, but was increased when propionate was fed in addition to acetate. This was reflected in an unchanged ability to clear an intravenous acetate load from the blood when acetate alone was added, but an increased acetate clearance rate when propionate was fed in addition to acetate. In Expt 3 the effects of supplementation with various propionate:acetate ratios were investigated. Acetate clearance was consistently increased by an increased propionate : acetate ratio. These results show that the metabolism of excess acetate is responsive to the dietary supply of glucose precursors, and provide support for the concept that additional glucose precursors are necessary for the efficient utilization of acetate when roughage diets low in protein are fed.
\end{abstract}

Acetate clearance rate: Gluconeogenesis : Ruminant

Forage diets typically give rise to a high rumen production rate of acetate relative to that of propionate. This is usually accompanied by a reduced supply of amino acids (mainly as microbial protein), and negligible amounts of glucose and lipids; this results in a high proportion of acetate relative to glucose precursors in the absorbed nutrients. As acetate is the major energy-yielding substrate under these conditions, the efficiency with which it is used will exert a dominant influence on the overall efficiency of feed utilization. As it has been proposed that an insufficient supply of glucose relative to acetate may reduce the efficiency with which acetate is utilized (Preston \& Leng, 1987), a need has arisen for some measure of the balance between the availability of acetate and precursors of glucose.

A number of workers (Jarrett et al. 1952; Pugh \& Scarisbrick, 1952; Reid, 1958; Jarrett \& Filsell, 1960; Egan, 1965) have made estimates of acetate clearance rate and, in general, higher rates of acetate clearance were associated with higher-quality diets. In reviewing the literature, Egan (1965) argued that factors influencing the rate of acetate oxidation or lipogenesis from acetate would include the availability of glucose or glucogenic substrates, and the nitrogen status of the animal. Weston (1966) found a linear relationship between

* Present address: Animal and Dairy Science Research Institute, Private Bag X2, Irene 1675, South Africa. 
level of feed intake and acetate clearance rate and argued that clearance could be explained in terms of the total availability of digestible nutrients. Weston's (1966) conclusions, together with the fact that Jarrett \& Filsell (1960) obtained no response to supplementation with propionate, appear to have had the effect of discouraging further use of the technique as there appears to be only one report (Ponto \& Bergen, 1974) of its application since 1966.

Despite these reports, re-analysis of all existing acetate clearance data (Preston \& Leng, 1987) shows a striking degree of correspondence between acetate clearance rate and an arbitrary estimate of glucogenic potential. In the studies reported here acetate clearance rate has been re-examined as a possible index of the balance of acetate to glucogenic nutrients in sheep fed on forage-based diets.

\section{MATERIALS AND METHODS \\ General}

All sheep were held in metabolism crates in continuously illuminated rooms. Diets were provided to animals in equal portions at two-hourly intervals by automatic feeding machines. Water was freely available at all times. Sheep were treated with antihelmintics before each experiment.

\section{Animals and diets}

Expt 1. Twelve Merino crossbred wethers $(27.7(\mathrm{SE} 0.3) \mathrm{kg})$ were assigned at random to one of two diets (six sheep/diet). The diets were $(a)$ basal, (b) basal plus $0.62 \mathrm{~mol}$ propionate/d (fed as sodium propionate). Both groups received the following treatments: 40,120 or $200 \mathrm{~g} / \mathrm{d}$ of a pelleted protein supplement in sequence. The basal diet consisted of chaffed wheat straw that had been sprayed with an aqueous solution of urea ( $20 \mathrm{~g} \mathrm{urea} / \mathrm{kg}$ straw) and sun-dried. This was fed at a level of $800 \mathrm{~g} / \mathrm{d}$ together with a complete mineral supplement. The protein supplement was formulated to contain a high proportion of bypass protein and consisted of a pelleted mixture of $(\mathrm{g} / \mathrm{kg}): 560$ cottonseed meal, 250 soya-bean meal, 50 meat meal, 50 dried molasses, 15 potassium chloride, 5 sodium chloride, 50 calcium hydrogen phosphate, 20 other minerals. The supplement contained $62 \mathrm{~g} \mathrm{~N} / \mathrm{kg}$ dry matter (DM), and the basal diet $18.4 \mathrm{~g} \mathrm{~N} / \mathrm{kg} \mathrm{DM}$. Nitrogen intakes for animals receiving the basal diet plus 40,120 or $200 \mathrm{~g} / \mathrm{d}$ supplement were 16,20 or $25 \mathrm{~g} / \mathrm{d}$ respectively. The mineral supplement provided $(\mathrm{g} / \mathrm{d})$ : calcium $1 \cdot 6$, phosphorus $1 \cdot 0$, sulphur 0.9 , sodium 3 , and trace minerals. Acetate clearance rate, acetate flux rate and glucose kinetics were measured.

Expt 2. Six cross-bred Merino wethers $(23.6(\mathrm{SE} 0.5) \mathrm{kg}$ ) were allocated to three treatments based on a diet of wheat straw $(650 \mathrm{~g} / \mathrm{d})$, urea $(12 \mathrm{~g} / \mathrm{d})$, a complete mineral mixture $(5 \mathrm{~g} / \mathrm{d})$ and the same pelleted protein supplement $(80 \mathrm{~g} / \mathrm{d})$ as used in Expt 1 in a cross-over design. The treatments consisted of: basal diet alone; basal plus $0.42 \mathrm{~mol}$ acetate $/ \mathrm{d}$; basal plus a mixture of $0.42 \mathrm{~mol}$ acetate $/ \mathrm{d}$ and $0.62 \mathrm{~mol}$ propionate $/ \mathrm{d}$. Acetate and propionate were fed as $\mathrm{Na}$ salts. All diets were adjusted to equal $\mathrm{Na}$ content $(39 \mathrm{~g} / \mathrm{kg})$ with sodium bicarbonate. The sheep were allowed $10 \mathrm{~d}$ to adjust to changes in their diets before each experiment was made. Acetate clearance rate, acetate flux rate and glucose kinetics were measured.

Expt 3. On completion of Expt 2, a second cross-over experiment was conducted using the same animals and basal diet. The treatments were: $0.46 \mathrm{~mol}$ propionate $/ \mathrm{d}$ plus $0.42 \mathrm{~mol}$ acetate $/ \mathrm{d}, 0.31 \mathrm{~mol}$ propionate $/ \mathrm{d}$ plus $0.42 \mathrm{~mol}$ acetate $/ \mathrm{d}, 0.15 \mathrm{~mol}$ propionate $/ \mathrm{d}$ plus $0.42 \mathrm{~mol}$ acetate/d. $\mathrm{NaHCO}_{3}$ was not added to these diets. In this experiment, only acetate clearance rate was measured. 


\section{Experimental procedures}

In Expt 1, carotid loops were inserted in the right carotid artery of all animals 2 months before the experiment, after which they were given a good-quality diet for approximately 1 month. The sheep were adapted to the wheat-straw diet for 3 weeks before the experiment, and to the experimental diets for $10 \mathrm{~d}$ before measurements were commenced. Catheters were inserted into the carotid artery and a jugular vein on the day preceeding the measurement period. All tracers were administered via the left jugular vein and blood samples were taken from the carotid artery. Acetate flux rate was measured on day 1 ; glucose irreversible loss rate (ILR) was measured during the morning of day 4 and acetate clearance rate during the afternoon of the same day.

In Expts 2 and 3, sheep were adapted to each diet for $10 \mathrm{~d}$ before commencing measurements and were prepared with catheters in both jugular veins on the day before the measurement periods. Tracers were injected via one of these catheters and samples of blood were drawn from the opposite catheter. In Expt 2, acetate flux rate was measured on day 1 of the measurement period, glucose ILR on day 2 and acetate clearance rate on day 5 . In Expt 3 only acetate clearance rate was measured.

Acetate flux rate. In Expt 1 a solution containing $123 \mu \mathrm{Ci}\left[1,2{ }^{14} \mathrm{C}\right]$ acetate in $75 \mathrm{ml}$ sterile physiological saline $(9 \mathrm{~g} \mathrm{NaCl} / 1)$ was infused for $5 \mathrm{~h}$ at a rate of $0.25 \mathrm{ml} / \mathrm{min}$ following an initial priming dose of $50 \mu \mathrm{Ci}$. Samples for determination of the specific radioactivity (SR) of blood acetate and bicarbonate- $\mathrm{C}$ were taken at hourly intervals during the acetate infusion. Blood samples were transferred immediately to McCartney bottles for bicarbonate analysis, and heparinized whole-blood samples for acetate analysis were stored at $-15^{\circ}$.

In Expt 2 acetate flux rate was determined using a mixture of equal quantities of $\left[1-{ }^{14} \mathrm{C}\right]-$ and $\left[2-{ }^{14} \mathrm{C}\right]$ acetate. A total of $143 \mu \mathrm{Ci}$ acetate was infused as described previously, but no priming dose was given. Blood samples were taken as described for Expt 1 at hourly intervals from the second hour of infusion onwards, but in this experiment the SR of acetate was determined from plasma samples and not from whole blood. Blood samples were taken into heparinized centrifuge tubes and immediately centrifuged at $2000 \mathrm{~g}$ for $15 \mathrm{~min}$. The plasma was removed and deproteinized with sulphosalicylic acid $(0.05 \mathrm{~g} / \mathrm{ml}$ plasma) and recentrifuged. The supernatant fraction was decanted and stored at $-15^{\circ}$ until analysis. The SR of acetate was determined using $1 \mathrm{ml}$ plasma samples which were analysed as described for acetate in whole blood.

Glucose flux rate. Glucose flux rate was estimated using $\left[2{ }^{3} \mathrm{H}\right]$ glucose. A single intravenous injection of $200 \mu \mathrm{Ci}$ (Expt 1) or $83 \mu \mathrm{Ci}$ (Expt 2) glucose in $5 \mathrm{ml}$ sterile physiological saline was administered. Blood samples were taken into heparinized tubes at $60,90,120,150,180$, and $210 \mathrm{~min}$ after administration of the tracer, centrifuged at $3000 \mathrm{~g}$ for $20 \mathrm{~min}$, and the plasma stored at $-15^{\circ}$.

Blood samples were also taken before all injections or infusions of tracers, and similarly prepared and analysed to enable background levels of radioactivity in blood metabolites to be determined.

Acetate clearance rate. A single dose of approximately $4 \mathrm{mmol}$ acetate $/ \mathrm{kg}$ live weight (as sodium acetate) in $50 \mathrm{ml}$ distilled water was administered via the jugular vein over a period of $3 \mathrm{~min}$. In Expt 1 samples of whole blood $(5 \mathrm{ml})$ were collected into heparinized tubes before injection and then at 20-min intervals for $2 \mathrm{~h}$ following the injection. In Expts 2 and 3 , acetate clearance rates were determined from plasma and not whole-blood samples. Samples were taken at 5 -min intervals for the first $30 \mathrm{~min}$ and 15 -min intervals for the subsequent $30 \mathrm{~min}$ following injection of the acetate load. Deproteinized plasma was prepared and stored for analysis as described previously for acetate flux rate determinations. 


\section{Analytical methods}

In Expt 1 acetate flux and clearance rates were determined from samples of whole blood. Acetate was isolated from $2 \mathrm{ml}$ whole blood by the freeze-transfer process of Pethick et al. (1981). Recovery was complete and linear throughout the range studied. The resultant sodium acetate was dried in a vacuum desiccator and taken up in $170 \mu \mathrm{l}$ of a sulphuric acid-metaphosphoric acid solution ( $20 \mathrm{~g}$ metaphosphoric acid/litre $1.85 \mathrm{M}-\mathrm{H}_{2} \mathrm{SO}_{4}$ ). Isobutyrate was added as an internal standard. Acetate concentrations were measured by gas-liquid chromatography on $5 \mu \mathrm{l}$ of the resulting solution. For assay of the radioactivity $100 \mu \mathrm{l}$ of the solution was added to $10 \mathrm{ml}$ Hionic Fluor (Packard Instrument Co., Illinois) and the mixture counted in a scintillation counter.

In Expt 2 the same methodology was employed for acetate flux analyses using $1 \mathrm{ml}$ plasma instead of whole blood. Acetate clearance rates were determined directly by injecting acidified plasma samples into the column of the gas-liquid chromatograph (Expts 2 and 3). Isobutyrate was added to the samples as an internal standard. For all analyses the column support was Chromosorb ' $\mathrm{W}$ ', acid-washed, 60-80 mesh (Johns-Manville, Colorado, USA), and the liquid phase was phosphoric acid $(0.015 \mathrm{w} / \mathrm{w})$ and polypropylene glycol sebacate $(0 \cdot 175 \mathrm{w} / \mathrm{w})$. The operating temperatures for the injector, column and detector were 210,135 and $180^{\circ}$ respectively.

Plasma glucose was isolated by the penta-acetate derivative method of Jones (1965). Radioactivity was counted in $5 \mathrm{ml}$ liquid scintillation cocktail containing $4 \mathrm{~g}$ PPO $(2,5-$ diphenyloxazole) and $0.2 \mathrm{~g}$ POPOP (1,4-bis-[2(5 phenyloxazolyl)]-benzene)/l toluene. Plasma glucose concentrations were analysed enzymically using an automated colorimetric method (Cobas Bio System; Hoffman-La Roche \& Co, Switzerland).

Bicarbonate in whole-blood samples was isolated by acidification and the precipitation of the carbon dioxide as barium carbonate (Leng \& Leonard, 1965). The SR was determined by counting a weighed amount of $\mathrm{BaCO}_{3}$ suspended in scintillation gel consisting of (g/l xylene): Cab-o-sil thixotropic powder (Packhard Instrument Co., Illinois) 34 , PPO 4, POPOP 0.2.

\section{Calculations}

Acetate clearance rate. Plasma and blood acetate concentrations were expressed as the natural logarithm of the difference between the measured concentration and the preloading concentration. The rate constant for clearance of the acetate load from the blood compartment $(k ; / \mathrm{min})$ was given by the exponent of a single exponential function describing the line of best fit (least squares) to the data representing the decline in the concentration of plasma acetate after acetate loading (see Fig. 1) i.e. $C_{t}=C_{o} e^{-k t}$, where $C$ is the concentration of acetate (corrected for base line) in plasma at time 0 or $t$ min. Acetate clearance rate $(k)$ was expressed as the proportion of the injected dose removed per min.

The volume of distribution of the acetate load was given by:

$$
\text { volume }(\mathrm{l})=\operatorname{acetate} \text { load }(\mathrm{mol}) / C_{o}(\mathrm{~mol} / \mathrm{l}) \text {, }
$$

where $C_{0}$ is the increment in blood acetate concentration after administration of the dose, given by the zero-time intercept (mol excess/1) of the relationship describing acetate concentration $v$. time.

The size of the blood acetate compartment before dosing was determined from the product of the volume of distribution of the acetate load (l) and the preloading blood acetate concentration ( $\mathrm{mol} / \mathrm{l})$.

Glucose and acetate kinetics. The rate of irreversible loss of acetate- $\mathrm{C}$ and the fraction of blood bicarbonate- $\mathrm{C}$ derived from blood acetate was determined by procedures described by Shipley \& Clarke (1972). The size and volume of distribution of the glucose 


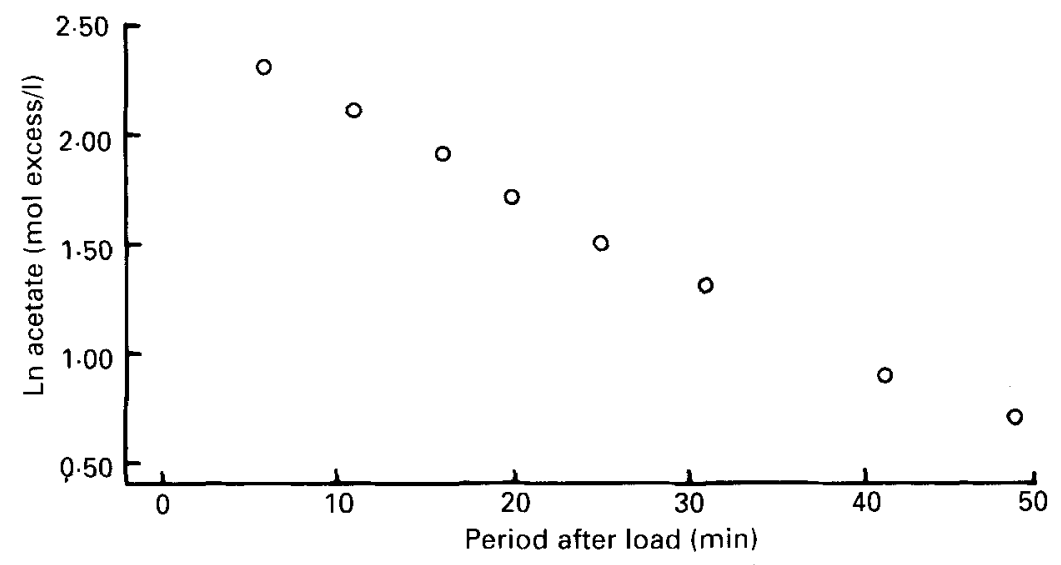

Fig. 1. Expt 3. Blood acetate concentration (mol excess/l) following intravenous administration of an acetate load. For details of procedures, see pp. 302-304.

compartment and total entry rate of glucose were determined by the monoexponential procedure described by Judson \& Leng (1972).

\section{Statistical analysis}

In Expt 1 six sheep were allocated to each of two treatments (with or without propionate supplementation); both groups were supplemented with 40,120 or $200 \mathrm{~g} / \mathrm{d}$ of protein supplement in sequence. Statistical analysis was conducted by analysis of variance as a split-plot design with linear and quadratic contrasts taken out for the effect of protein using a computer program (Lawes Agricultural Trust, 1980). There were $20 \mathrm{df}$ for sub-plot error. In Expt 2 six sheep were allocated to the three treatments in a cross-over design for three treatments with two replicates of each sequence. During one of the periods, measurements were not conducted on one of the sheep due to feed refusal. Statistical analysis was by analysis of variance and there were $7 \mathrm{df}$ for error. On completion of Expt 2 a second crossover trial was conducted using the same animals (Expt 3). Statistical analysis was by analysis of variance and there were $8 \mathrm{df}$ for error.

\section{RESULTS}

\section{Acetate clearance rate}

For all animals the decline in acetate concentration after loading was well described by a single exponential function (see Fig. 1). In some experiments, samples taken after $60 \mathrm{~min}$ had blood acetate concentrations that were equal to or lower than the pre-injection levels. Only values obtained before 60 min were used to fit curves of acetate concentration $v$. time. Acetate concentrations in blood or plasma after the injection were adjusted for preinjection concentration, and the linear regression of log acetate concentration (mol/1) $v$. time accounted for $0.91-0.99$ of the variance.

The pre-loading acetate concentrations in the blood and the estimates of acetate compartment size, volume of distribution of acetate and acetate clearance rate in Expts 1 , 2 and 3 are given in Tables 1,2 and 3 respectively.

In Expt 1 the volume of distribution of acetate was equivalent to $35-56 \%$ of live weight. Blood acetate concentrations were decreased by propionate supplementation $(P<0.01)$, but not by protein supplementation. Acetate clearance rate was increased $(P<0.01)$ by supplementation with both propionate and protein. 
P. B. CRONJÉ AND OTHERS
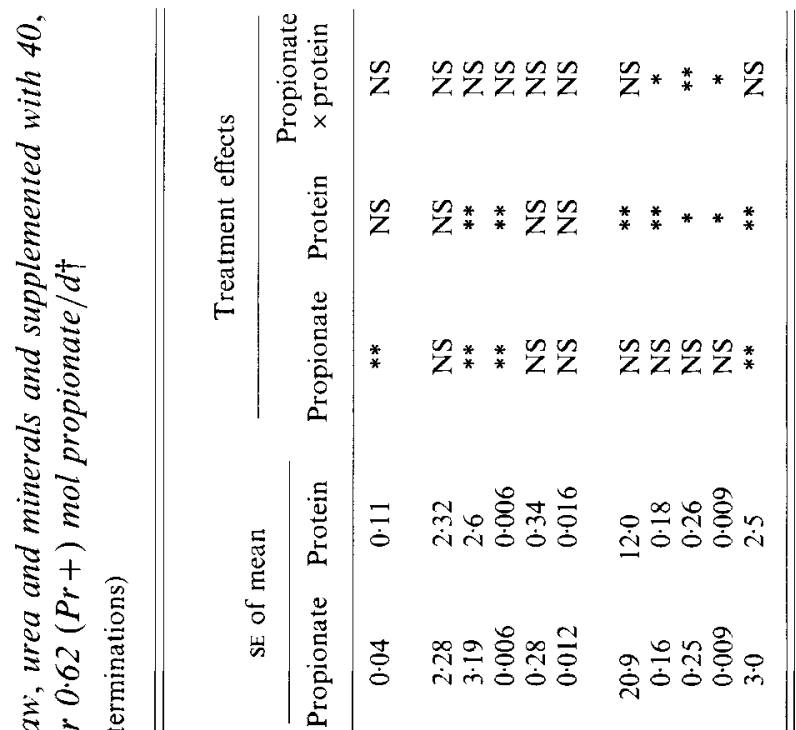
Table 2. Expt 2. Acetate and glucose kinetics in sheep fed on a basal diet of wheat straw plus urea, minerals and $80 \mathrm{~g} / \mathrm{d}$ of a protein meal alone or supplemented with acetate or acetate plus propionate

(Mean values and standard errors ( $\mathrm{SE}$ ) for no. of determinations shown)

\begin{tabular}{|c|c|c|c|c|c|c|c|}
\hline $\begin{array}{l}\text { Supplement ... } \\
\text { Propionate supplement }(\mathrm{mol} / \mathrm{d}) \ldots \\
\text { Acetate supplement }(\mathrm{mol} / \mathrm{d}) \ldots \\
\text { Molar ratio (propionate: acetate) ... }\end{array}$ & $\begin{array}{l}\text { Acetat } \\
0 \\
0 \cdot 4 \\
0\end{array}$ & & $\begin{array}{c}\text { Basal } \\
0 \\
0 \\
-\end{array}$ & & $\begin{array}{r}\text { Acetate } \\
\text { propion } \\
0.62 \\
0.42 \\
1.48\end{array}$ & & \\
\hline Molar ratio (propionate: acetate) ... & Mean & $n$ & Mean & $n$ & Mean & $n$ & SE \\
\hline Plasma acetate concentration ( $\mathrm{mM}$ ) & $1 \cdot 25$ & 6 & $1 \cdot 33$ & 6 & $1 \cdot 29$ & 5 & $0 \cdot 39$ \\
\hline Acetate clearance rate $(/ \mathrm{min})$ & $0.033^{\mathrm{a}}$ & 6 & $0.037^{\mathrm{a}}$ & 6 & $0.054^{\mathrm{b}}$ & 5 & 0.005 \\
\hline Acetate flux rate $(\mathrm{mol} / \mathrm{d})$ & 1.57 & 6 & $1 \cdot 60$ & 6 & $2 \cdot 49$ & 5 & 1.45 \\
\hline Plasma glucose concentration (mg/l) & 599 & 6 & 611 & 6 & 628 & 5 & 24.8 \\
\hline Glucose compartment size $(\mathrm{g})$ & $3 \cdot 04$ & 6 & $2 \cdot 99$ & 6 & $3 \cdot 25$ & 5 & $0 \cdot 16$ \\
\hline Glucose volume of distribution (l) & $5 \cdot 10$ & 6 & $4 \cdot 87$ & 6 & $5 \cdot 17$ & 5 & 0.39 \\
\hline Glucose irreversible loss rate $(\mathrm{g} / \mathrm{d})$ & $55 \cdot 3^{a}$ & 6 & $55 \cdot 9^{\mathrm{a}}$ & 6 & $75 \cdot 1^{\mathrm{b}}$ & 5 & 4.08 \\
\hline
\end{tabular}

a,b Means with different superscript letters were significantly different $(P<0.01)$.

* For details of procedures, see pp. 302-304.

Table 3. Expt 3. Acetate clearance rate in sheep fed a basal diet of wheat straw plus urea, minerals and $80 \mathrm{~g} / d$ of a protein meal and supplemented with acetate plus different amounts of propionate

(Mean values with their standard errors for six animals)

\begin{tabular}{|c|c|c|c|c|}
\hline Propionate:acetate... & $0 \cdot 36$ & 0.74 & $1 \cdot 1$ & \\
\hline Propionate supplement $(\mathrm{mol} / \mathrm{d}) \ldots$ & 0.15 & $0 \cdot 31$ & 0.46 & $\mathrm{SE}$ \\
\hline Acetate supplement $(\mathrm{mol} / \mathrm{d}) \ldots$ & $0 \cdot 42$ & 0.42 & $0 \cdot 42$ & \\
\hline Plasma acetate concentration (mM) & $1 \cdot 20$ & $1 \cdot 01$ & $1 \cdot 11$ & $0 \cdot 18$ \\
\hline Acetate clearance rate $(/ \mathrm{min})$ & $0.035^{\Omega}$ & $0.041^{a b}$ & $0.048^{\mathrm{b}}$ & 0.005 \\
\hline
\end{tabular}

a." Means with different superscript letters were significantly different $(P<0.01)$.

For details of procedures, see pp. 302-304.

In Expt 2 acetate clearance rate was decreased slightly by the addition of acetate to the basal diet, but greatly increased $(P<0.01)$ by the addition of propionate plus acetate to the diet. In Expt 3 acetate clearance rate was increased as the propionate:acetate ratio was increased from 0.36 to $1 \cdot 1$. Fig. 2, in which the values for Expts 2 and 3 have been combined, clearly shows that the rate of clearance increased as the propionate: acetate ratio added to the diet increased.

\section{Acetate flux and oxidation}

The SR of acetate appeared to have reached a plateau value within $1 \mathrm{~h}$ of the commencement of the primed infusion of $\left[{ }^{14} \mathrm{C}\right]$ acetate, and the plateau for bicarbonate within $2 \mathrm{~h}$. The SR remained relatively constant on plateau until the infusion was terminated, after which the acetate SR declined rapidly and the SR of bicarbonate-C declined more slowly. In Expt 2 acetate SR had reached a plateau within 2 h. Acetate flux rates for Expts 1 and 2 are shown in Tables 1 and 2 respectively, and the fractions of blood bicarbonate- $C$ derived from acetate $(0 \cdot 20-0 \cdot 25)$, obtained from the ratios of specific radioactivities between 2 and $5 \mathrm{~h}$ of infusion in Expt 1, are given in Table 1. Although 


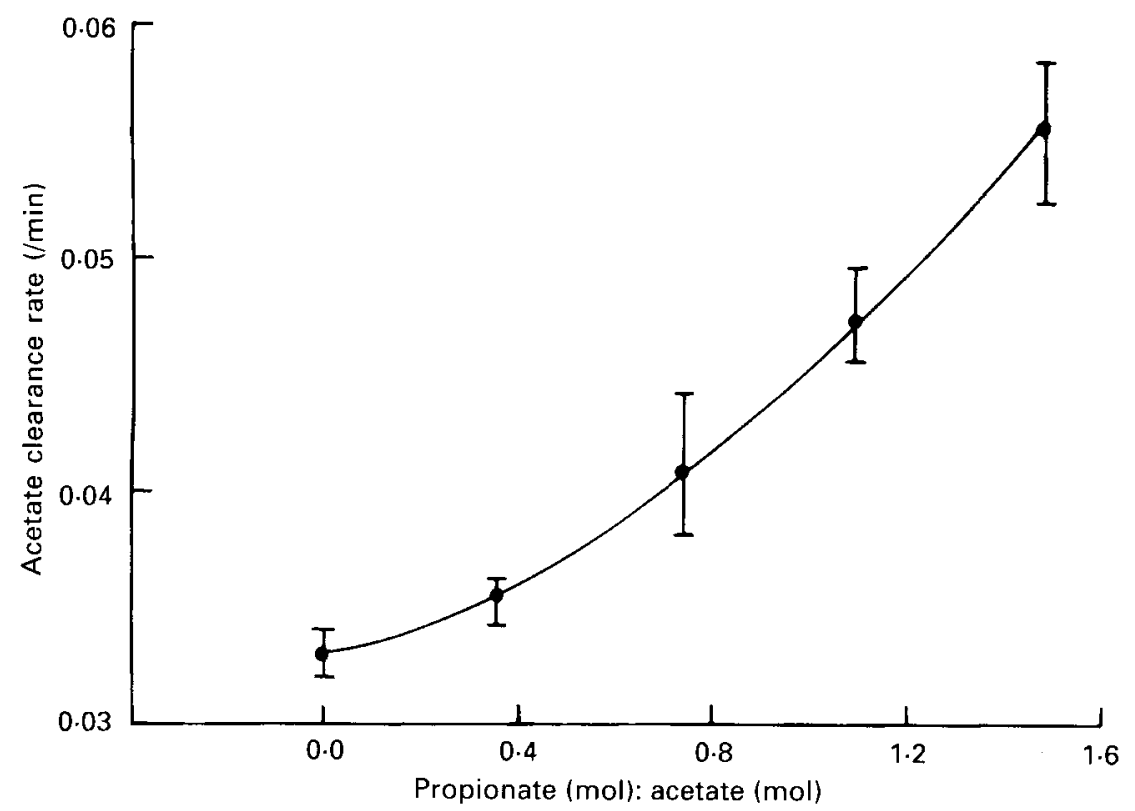

Fig. 2. Expts 2 and 3. Acetate clearance rates in sheep fed on a basal diet of wheat straw plus urea supplemented with various propionate: acetate ratios. Points are mean values with their standard errors represented by vertical bars. For details of procedures, see pp. $302 \cdot 304$.

acetate flux tended to increase with increasing propionate supplementation in both trials, the differences were statistically non-significant $(P>0 \cdot 05)$.

\section{Glucose kinetics}

The concentrations of glucose in blood plasma were found to be almost constant during the 210 min after administration of the $\left[{ }^{3} \mathrm{H}\right]$ glucose tracer. The decline in plasma glucose SR with time (between 60 and $210 \mathrm{~min}$ ) was well described by a single exponential function, and the linear regression of $\log (\mathrm{SR}) v$. time removed more than 0.98 of the variance in all sheep. The mean plasma glucose concentrations, volumes of distribution of glucose, compartment sizes and ILR of glucose for Expts 1 and 2 are given in Tables 1 and 2 respectively. In Expt 1 glucose ILR was positively related $(P<0.01)$ to the levels of supplementation with both propionate and protein pellets. In Expt 2 glucose ILR was not increased by acetate supplementation, but was significantly higher $(P<0.01)$ when propionate was fed in conjunction with acetate (Table 2$)$; similar differences were also apparent with respect to compartment size $(P<0.05)$.

\section{DISCUSSION}

Armstrong \& Blaxter (1957) showed that the efficiency of utilization of acetate was low when infused into the rumen as the only energy source, but was increased by the addition of propionate. A viable explanation for this is that glucose precursors such as propionate provide a source of NADPH (via gluconeogenesis and the pentose phosphate cycle) necessary for the conversion of acetate to fatty acids, without which acetate would be diverted to futile cycles and lost as heat (see Preston \& Leng, 1987). Although several other regulatory mechanisms such as the supply of oxaloacetate (Armstrong \& Blaxter, 1957), activity of acetyl-CoA carboxylase (EC 6.4 1.2) and effects of insulin (Vernon, 1981, 1989) 
may also provide an explanation for these results, the relative importance of factors limiting acetate metabolism is unclear. The NADPH theory would suggest that significant benefits may be derived by supplementing ruminants fed on forage diets of low digestibility and protein content with a source of glucogenic precursors such as protein or starch (Preston \& Leng, 1987). Although this view is supported by the results of simulation models (Baldwin et al. 1976; Black et al. 1984), and evidence showing that the efficiency of utilization of acetate and the in vitro conversion of acetate to fatty acids is increased by glucose precursors (Yang \& Baldwin, 1973; Tyrrell et al. 1979), this hypothesis is not universally accepted and has been the subject of much debate (Blaxter, 1979; Ørskov \& McDonald, 1979; MacRae \& Lobley, 1982; Preston \& Leng, 1987).

Resolution of the controversy regarding interactions between glucose and acetate is hampered by methodological difficulties: calorimetry provides only an indirect assessment of the conversion of acetate to lipid, estimates of gluconeogenesis are complicated by crossover of label in the tricarboxylic acid cycle and interpretation of in vivo estimates of acetate flux are complicated by a large endogenous component.

In experiments reported here acetate flux rate appeared to be increased by propionate supplementation, but these tendencies did not attain statistical significance. Armstrong \& Blaxter (1957) found no evidence of effects on rumen or metabolic variables when infusing vastly greater amounts of VFA, and acetate flux rates in the blood observed in the present study $(1.6-3.8 \mathrm{~mol} / \mathrm{d})$ were also within the limits of previous estimates which range from 1.7 to $3.1 \mathrm{~mol} / \mathrm{d}$ (Giesecke, 1983; Van der Walt, 1984). The lack of a significant response of acetate flux rate to dietary manipulation in the present report and others (König et al. 1984) could possibly be due to endogenous acetate production which may constitute up to $25 \%$ of the total flux and, thus, obscure changes in the dietary component (Annison et al. 1967). In contrast, acetate clearance rate was shown to be extremely responsive to dietary changes.

In a fed animal an intravenous acetate load should be cleared by conversion of acetate into fat as the oxidative energy needs are satisfied by the basal diet. Acetate is transferred across the cell membranes of adipose tissue and muscle by passive diffusion (Madsen, 1983). The rate of transport is, thus, dependent on the concentration gradient. Clearance of an acetate load will, therefore, reflect the potential maximum rate of intracellular acetate metabolism, as little acetate is voided in the urine following an acetate load (Pugh \& Scarisbrick, 1952). A relatively high rate of clearance of an intravenously administered load from the circulating blood could, therefore, be indicative of an appropriate balance of acetate to propionate or amino acids, or both, among the nutrients available for tissue metabolism.

In Expt 1 it was shown that protein and propionate supplementation increased both acetate clearance rate and glucose ILR. Although these sources were not used with equal efficacy for glucose production, acetate clearance rate was positively related $(P<0.01)$ to glucose IRL irrespective of precursor over a range of glucose ILR which varied from 55 to $121 \mathrm{~g} / \mathrm{d}$.

In Expt 2 glucose ILR was not increased by dietary acetate supplementation. When propionate was fed in conjunction with acetate, however, glucose ILR was increased markedly. These results suggest that the inability to produce additional glucose in response to an acetate challenge was not due to an absence of demand but to an insufficient supply of dietary glucose precursors. The insufficient supply of glucose precursors was reflected in a decreased ability to clear an intravenously administered acetate load from the body when supplemental acetate was added to the diet, but an enhanced ability when propionate was fed in conjunction with acetate.

Acetate clearance rates were also increased by increased propionate:acetate ratios in Expt 3, in which values intermediate between the extremes given in Expt 2 were examined. 


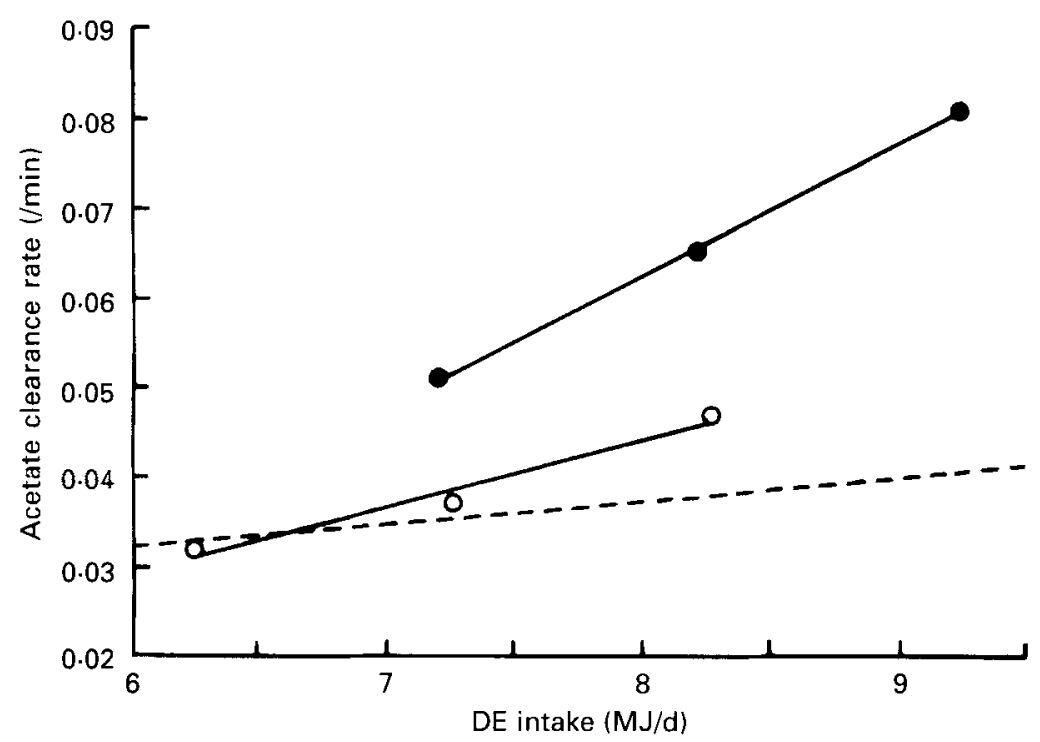

Fig. 3. Relationship between acetate clearance rate and estimated digestible energy (DE) intake in sheep fed on a basal diet of wheat straw plus urea with $(-0)$ or without $(\mathrm{O}-0) 0.62 \mathrm{~mol}$ propionate/d and supplemented with 40,120 , or $200 \mathrm{~g} / \mathrm{d}$ of a protein meal. The ME content of wheat straw and the protein supplement was assumed to be 7.64 and $13.57 \mathrm{MJ} / \mathrm{kg}$ DM respectively, and that of sodium propionate to be $1.535 \mathrm{MJ} / \mathrm{mol}$. The relationship established by Weston (1966) is included for comparison (---). For details of procedures, see pp. 302-304.

Fig. 2, in which values derived from both experiments have been combined, shows that the response was consistent over a wide range. Various workers (Jarrett et al. 1952; Pugh \& Scarisbrick, 1952; Reid, 1958; Jarrett \& Filsell, 1961; Egan, 1965) have suggested that the rate of clearance of an intravenous acetate load may indicate the ability of a diet to provide substrates (such as glucose) needed to enable the efficient uptake or oxidation, or both, of acetate by tissues. However, Weston (1966) suggested that caution should be exercised when interpreting differences between diets when these provided different levels of digestible energy (DE), and suggested that acetate clearance rate was related to DE intake. The concept that acetate clearance rate might be an index of the balanced nature of the nutrients absorbed has apparently not been re-examined since that time. Since 1966, however, it has been shown that the degradability of dietary protein in the rumen, particularly of dried forages, decreases as quantity of feed consumed increases (Cronjé, 1983); and the ratio of absorbed amino acids, relative to microbial fermentation products, is altered accordingly, i.e. the balance of nutrients is affected by level of feeding. The absorption of increasing amounts of amino acids as feed intake increases may explain the linear increase in acetate clearance rate that was shown to occur (Weston, 1966) in response to increased lucerne (Medicago sativa) hay intake. Weston (1966) estimated the half-time for clearance of an acetate load in sheep given chaffed lucerne hay at five levels varying from 2.9 to $11.7 \mathrm{MJ} \mathrm{DE} / \mathrm{d}$. We have expressed Weston's (1966) results as a fractional rate of clearance/min (i.e. $\log _{\mathrm{e}}(2) /$ half-time $(\mathrm{min})$ ) and the relationship between fractional clearance rate and DE accounts for 0.99 of the variance. The correlation suggests that acetate clearance rate might be used to predict DE intake of animals on a single forage with considerable precision. The results from the study now presented, however, clearly indicate that the relationship would change for other diets according to the amounts and ratios of amino acids or propionate in the absorbed nutrients (Fig. 3).

Increases in the amount of amino acids in the absence of supplementary propionate 
resulted in increases in fractional acetate clearance that were closer to the relationship of Weston (1966) than those obtained from propionate. This may indicate that protein and propionate are not used with equal efficacy for gluconeogenesis as suggested by the corresponding increases in glucose ILR.

Evidence in support of the contention that the efficiency of utilization of acetate is dependent on an adequate supply of glucose precursors has been obtained in calorimetric studies in which it has been shown that the heat increment of acetate is reduced by the addition of glucose precursors to the diet (Armstrong \& Blaxter, 1957; Hovell \& Greenhalgh, 1978; Tyrrell et al. 1979). Nevertheless, there are also several reports in which no such response to additional glucose precursors was obtained (Hovell et al. 1976; Ørskov et al. 1979), but the relatively high level of amino acids supplied intragastrically to the sheep in these diets may have provided adequate glucose precursors. Although MacRae \& Lobley (1982) have attempted to reconcile differing results on similar grounds, this subject remains contentious. Such reconciliation can only be partly successful, as the critical variable is not the quantity of glucose precursors in the diet, but the glucose precursors:acetate ratio produced, as shown in the present study. Also, the efficiency with which individual glucose precursors are converted to glucose is not constant but is determined in turn by their proportions relative to each other.

Substantial improvements in efficiency of feed utilization can be expected in response to supplementation with bypass protein and starch (Egan, 1977; Hennessy, 1984; Lee et al. 1985), but accurate assessment of supplementary needs using existing techniques under changing field conditions is difficult. Furthermore, such improvements would not be predicted by current ME systems as small amounts of protein supplement have little effect on the ME content of the diet. It is suggested that the measurement of acetate clearance rate could be used to good advantage to investigate nutrient interactions in ruminants fed on forage diets, and possibly to evaluate the adequacy of feed supplements.

The authors wish to thank Messrs S. Stachiw and F. Ball, and Mrs M. Goosem for their excellent technical assistance and advice. This work was conducted while P.B.C. was on study leave from the Animal and Dairy Science Research Institute, Irene, South Africa, whose assistance and help is gratefully acknowledged.

\section{REFERENCES}

Annison, E. F., Brown, R. E., Leng, R. A., Lindsay, D. B. \& West, C. E. (1967). Rates of entry and oxidation of acetate, glucose, $\mathrm{D}(-)$ - $\beta$-hydroxybutyrate, palmitate, oleate and stearate, and rates of production and oxidation of propionate and butyrate in fed and starved sheep. Biochemical Journal 104, 135-147.

Armstrong, D. G. \& Blaxter, K. L. (1957). The heat increment of steam-volatile fatty acids in fasting sheep. British Journal of Nutrition 11, 247-272.

Baldwin, R. L., Yang, Y. T. \& Grichting, G. (1976). Theoretical model of ruminant adipose tissue metabolism in relation to the whole animal. Federation Proceedings 35, 2314-2318.

Black, J. L., Gill, M. \& Thornley, J. H. M. (1984). Efficiency of acetate utilization by ruminants. In Ruminant Physiology-Concepts and Consequences, p. 288 [S. K. Baker, J. M. Gawthorn, J. B. Mackintosh and D. B. Purser, editors]. Perth: University of Western Australia.

Blaxter, K. L. (1979). Discussion paper: use of energy for maintenance and growth. In Energy Metabolism, pp. 183-187 [L. E. Mount, editor]. London: Butterworths.

Cronje, P. B. (1983). Protein degradation in the rumen - The effect of basal diet and a comparison of techniques. MSc Thesis, University of Stellenbosch.

Egan, A. R. (1965). Nutritional status and intake regulation in sheep. Australian Journal of Agricultural Research 16. $473-483$.

Egan, A. R. (1977). Nutritional status and intake regulation in sheep. VIII. Relationships between the voluntary intake of herbage by sheep and the protein/energy ratio in the digestion products. Australian Journal of Agricultural Research 28, 907-915.

Giesecke, D. (1983). Plasma free fatty acids. In Dynamic Biochemistry of Animal Production, pp. 197-214 [P. M. Riis, editor]. Amsterdam: Elsevier. 
Hennessy, D. W. (1984). The role of protein in improving production of cattle grazing native pastures in subtropical New South Wales. PhD Thesis, University of New England.

Hovell, F. D. DeB. \& Greenhalgh, J. F. D. (1978). The utilization of diets containing acetate, propionate or butyrate salts by growing lambs. British Journal of Nutrition 40, 171-183.

Hovell, F. D. DeB., Greenhalgh, J. F. D. \& Wainman, F. W. (1976). The utilization of diets containing acetate salts by growing lambs as measured by comparative slaughter and respiration calorimetry, together with rumen fermentation. British Journal of Nutrition 35, 343-363.

Jarrett, I. G. \& Filsell, O. H. (1960). The effect of diet on acetate tolerance in sheep. Australian Journal of Experimental Biology and Medical Science 38, 347-353.

Jarrett, I. G. \& Filsell, O. H. (1961). An effect of glucose on acetate metabolism in sheep. Nature 190, 1114-1115.

Jarrett, I. G., Potter, B. J. \& Filsell, O. H. (1952). Lower fatty acids in the intermediary metabolism of sheep. Australian Journal of Experimental Biology and Medical Science 30, 197-206.

Jones, G. B. (1965). Determination of the specific activity of labeled blood glucose by liquid scintillation using glucose pentaacetate. Analytical Biochemistry 12, 249-258.

Judson, G. J. \& Leng, R. A. (1972). Estimation of the total entry rate and resynthesis of glucose in sheep using glucoses uniformly labelled with ${ }^{14} \mathrm{C}$ and variously labelled with ${ }^{3} \mathrm{H}$. Australian Journal of Biological Science 25 , $1313-1332$.

König, B. A., Oldham, J. D. \& Parker, D. S. (1984). The effect of abomasal infusions of casein on acetate, palmitate and glucose kinetics in cows during early lactation. British Journal of Nutrition 52, 319-328.

Lawes Agricultural Trust (1980). Genstat V. Mark 4.03, Rothamsted Experimental Station, Harpenden, Herts.

Lee, G. I., Hennessy, D. W., Williamson, P. J., Nolan, J. V., Kempton, T. J. \& Leng, R. A. (1985). Responses to protein meal supplements by lactating beef cattle given a low-quality pasture hay. Australian Journal of Agricultural Research 36, 729-741.

Leng, R. A. \& Leonard, G. J. (1965). Measurement of the rates of production of acetic, propionic and butyric acids in the rumen of sheep. British Journal of Nutrition 19, 469484.

MacRae, J. C. \& Lobley, G. E. (1982). Some factors which influence thermal energy losses during the metabolism of ruminants. Livestock Production Science 9, 447-456.

Madsen, A. (1983). The molecular basis of animal production: metabolism in skeletal muscle cells. In Dynamic Biochemistry of Animal Production, pp. 9-28 [P. M. Riis, editor]. Amsterdam: Elsevier.

Ørskov, E. R., Grubb, D. A., Smith, J. S., Webster, A. J. F. \& Corrigal, W. (1979). Efficiency of utilization of volatile fatty acids for maintenance and energy retention in sheep. British Journal of Nutrition 41, 541-551.

Ørskov, E. R. \& McDonald, I. (1979). Utilization of volatile fatty acids for maintenance and for energy retention. In Energy Metabolism, pp. 147-150 [L. E. Mount, editor]. London: Butterworths.

Pethick, D. W., Lindsay, D. B., Parker, P. J. \& Northrop, A. J. (1981). Acetate supply and utilization by the tissues of the sheep in vivo. British Joumal of Nutrition 46,97-110.

Ponto, K. H. \& Bergen, W. G. (1974). Developmental aspects of glucose and VFA metabolism in the germfree and conventional ruminant. Journal of Animal Science 38, 893-899.

Preston, T. R. \& Leng, R. A. (1987). Matching Ruminant Production Systems with Available Resources in the Tropics and Sub-Tropics. Armidale, Australia: Penambul Books.

Pugh, P. S. \& Scarisbrick, R. (1952). Acetate metabolism in ovine ketosis. Nature 170, 978-979.

Reid, R. L. (1958). Studies on the carbohydrate metabolism of sheep. VII. Intravenous glucose and acetate tolerance tests. Australian Journal of Agricultural Research 9, 788-796.

Shipley, R. A. \& Clarke, R. E. (1972). Tracer Methods for in vivo Kinetics. Theory and Applications. London: Academic Press.

Tyrrell, H. F., Reynolds, P. J. \& Moe, P. W. (1979). Effect of diet on partial efficiency of acetate use for body tissue synthesis by mature cattle. Journal of Animal Science 48, 598-606.

Van der Walt, J. G. (1984). Metabolic interactions of lipogenic precursors in the ruminant. ln Herbivore Nutrition in the Subtropics and Tropics, pp. 571-593 [F. M. C. Gilchrist and R. 1. Mackie, editors]. Craighall, South Africa: The Science Press.

Vernon, R. G. (1981). Lipid metabolism in the adipose tissue of ruminant animals. In Lipid Metabolism in Ruminant Animals, pp. 279-362 [W. W. Christie, editor]. Oxford: Pergamon Press.

Vernon, R. G. (1989). Endocrine control of metabolic adaptation during lactation. Proceedings of the Nutrition Society 48, 23-32.

Weston, R. H. (1966). The effect of level of feeding on acetate tolerance in the sheep. Australian Journal of Agricultural Research 17, 933-937.

Yang, Y. T. \& Baldwin, R. L. (1973). Preparation and metabolism of isolated cells from bovine adipose tissue. Journal of Dairy Science 56, 350-365. 